\title{
Nucleotide-induced mucin release from primary hamster tracheal surface epithelial cells involves the $P_{2 u}$ purinoceptor
}

\author{
K.C. Kim*, H.R. Park*, C.Y. Shin**, T. Akiyama*, K.H. Ko**
}

\begin{abstract}
Nucleotide-induced mucin release from primary hamster tracheal surface epithelial cells involves the $P_{2 u}$ purinoceptor. K.C. Kim, H.R. Park, C.Y. Shin, T. Akiyama, K.H. Ko. (C)ERS Journals Ltd 1996.

ABSTRACT: Mucin release by airway surface epithelial cells is regulated by extracellular adenosine triphosphate (ATP) via a $\mathbf{P}_{2}$ purinoceptor-mediated mechanism. The objective of the present experiment was to examine the possible involvement of uridine triphosphate (UTP) in this purinergic signal transduction pathway.

Using primary hamster tracheal surface epithelial cells, ATP and UTP were compared in their abilities: 1) to displace ATP $\gamma \mathrm{S}^{35}$-binding to intact cells; 2) to accumulate inositol phosphates; and 3) to stimulate mucin release. Finally, the presence of a $P_{2 u}$ receptor message was examined.

Our results showed that: 1) UTP was much less effective than ATP in displacing $\mathrm{ATP} \gamma \mathrm{S}^{35}$-binding (median inhibitory concentrations (IC50s) 240 vs $2.9 \mu \mathrm{M}$ ); 2) UTP was more potent than ATP in accumulating inositol phosphates (100 vs $43 \%$ increase at $2 \mathrm{mM}$ ); 3) UTP was equipotent with ATP in stimulating mucin release; 4) Northern blot analysis of messenger ribonucleic acids (mRNAs) with a mouse $P_{2 u}$ receptor complementary deoxyribonucleic acid (cDNA) probe revealed a single specific band $(2.8 \mathrm{~kb})$, partial sequencing of which showed a great homology with those of human or mouse $P_{2 u}$ receptors.

We conclude that, although both ATP and UTP are equipotent in stimulating mucin release, their binding kinetics to the cell surface are quite different, suggesting the presence of a common binding domain which may be responsible for the mucin release by these nucleotides. We suggest that the $P_{2 u}$ purinoceptor is likely to be responsible for mucin release by these nucleotides, probably via activation of phospholipase $\mathrm{C}$.
\end{abstract}

Eur Respir J., 1996, 9, 542-548.

\author{
*Dept of Pharmaceutical Sciences, University \\ of Maryland School of Pharmacy, Baltimore, \\ MD, USA. **Dept of Pharmacology, Seoul \\ University College of Pharmacy, Seoul, \\ Korea. \\ Correspondence: K. Chul Kim \\ Dept of Pharmaceutical Sciences \\ University of Maryland School of Pharmacy \\ 20 North Pine Street, Rm 446 \\ Baltimore \\ Maryland 21201 \\ USA \\ Keywords: Goblet cell \\ mucin \\ uridine triphosphate
}

Received: May 51995

Accepted after revision November 191995

This work was supported by a grant HL47125 from the National Institutes of Health.
In the airway, mucus plays an important role in the host's defence, and its proper function is believed to be attributed mainly to the quality and quantity of mucus glycoproteins or mucins which are present in the mucus. These airway mucins are secreted by two types of cell; goblet cells of the surface epithelium and mucous cells of the submucosal gland. It has been shown that secretion of airway goblet cell mucin is stimulated by extracellular nucleotides [1] by binding to $\mathrm{A}_{2}$ purinoceptor located on the cell membrane [2-4], which is coupled to phospholipase C (PLC) through, at least in part, pertussis toxin-sensitive G proteins [5]. Recently, LETHEM et al. [4] demonstrated that uridine triphosphate (UTP) is almost equipotent with adenosine triphosphate (ATP) in its ability to stimulate mucin release from human airway epithelial explants [4], suggesting the presence of a receptor type specific both for ATP and UTP in airway epithelial cells, which may regulate the mucin release.

The presence of this type of purinoceptor has been identified in a number of systems [6, 7], including airway epithelial cells, which involve the regulation of ion transport $[8,9]$, and have recently been classified as the
$\mathrm{P}_{2 \mathrm{u}}$ receptors purely based on agonist potency orders in which UTP $=$ ATP $>$ ATP $\gamma$ S $>2$-methylthio ATP $>\alpha, \beta$ methylene ATP [6]. However, our recent binding study indicated that, whilst there appears to be a good correlation between the mucin-releasing potency and the ATP $\gamma$ $\mathrm{S}^{35}$ displacement potency among various nucleotides, the ATP $\gamma \mathrm{S}^{35}$ displacement potency of UTP was, surprisingly, lower than ATP [10].

Despite a plethora of information regarding the $\mathrm{P}_{2 \mathrm{u}}$ receptor in various systems, great variations among these systems make it difficult to conclude whether or not these nucleotides indeed act through the same mechanism, especially in the regulation of airway mucin secretion. Therefore, in the present experiment, this problem was approached by directly comparing these two nucleotides using a primary airway epithelial cell culture system, which has been well characterized for secretion of mucin both biochemically and morphologically $[11,12]$. This is the first report which attempts to elucidate the biochemical mechanism of the nucleotide-induced mucin release at various levels, from receptor-binding to actual secretion. 


\section{Materials and methods}

\section{Primary hamster tracheal surface epithelial (HTSE) cell culture}

Tracheas were obtained from male golden Syrian hamsters, 8-10 weeks of age (Harlan Sprague Dawley, Indianapolis, Indiana, USA). HTSE cells were harvested and cultured as described previously [11]. A complete medium contained Medium 199/Dulbecco's modified medium $(1: 1)$ supplemented with insulin $\left(5 \mu \mathrm{g} \cdot \mathrm{mL}^{-1}\right)$, transferrin $\left(5 \mu \mathrm{g} \cdot \mathrm{mL}^{-1}\right)$, epidermal growth factor $\left(12.5 \mathrm{ng} \cdot \mathrm{mL}^{-1}\right)$, hypothalamic acid extract $\left(20 \mu \mathrm{g}\right.$ protein $\left.\cdot \mathrm{mL}^{-1}\right)$, retinoic acid $(0.1 \mu \mathrm{M})$, hydrocortisone $(0.1 \mu \mathrm{M})$, sodium selenite $(10 \mathrm{nM})$, and $5 \%$ foetal bovine serum (Hyclone). Briefly, cells plated on a thick collagen gel grow rapidly and reach confluence at Day 5. Confluent cultures are highly enriched with secretory cells $(>90 \%)$ [11], and secrete mucins which are virtually indistinguishable from in vivo mucins based on their size and sugar composition [12].

For displacement experiments, epithelial cells dissociated from 2.5 tracheas were plated on a $100 \mathrm{~mm}$ tissue culture dish (Falcon), which contained a thick collagen gel (7 mL·dish $\left.{ }^{-1}\right)$ (Celtrix Lab., Palo Alto, CA, USA) prepared as described previously [11].

\section{Dissociation of HTSE cells from the collagen matrix}

At confluence (Day 6), each culture was treated with Type IV collagenase $(4,000 \mathrm{U}$ in $5 \mathrm{~mL}$ phosphate-buffered saline (PBS); Worthington Biochem. Inc.) for 4-5 h inside a $37^{\circ} \mathrm{C} \mathrm{CO}_{2}$ incubator. After digestion of the collagen gel matrix, dissociated monolayer sheets were broken by gently pipetting repeatedly with a $10 \mathrm{~mL}$ pipette. The cell suspension was pelleted by centrifugation at $100 \times \mathrm{g}$ for $10 \mathrm{~min}$ at $4^{\circ} \mathrm{C}$, and the resulting cell pellet was washed once with PBS $\left(10 \mathrm{~mL} \cdot \mathrm{dish}^{-1}\right)$ by centrifugation. The final cell pellet was suspended in cold PBS and its protein concentration was measured using the Bradford protein assay (Bio-Rad kit) with human serum albumin as a standard. Confluent cells harvested from a $100 \mathrm{~mm}$ dish provided 4-6 $\mathrm{mg}$ proteins.

\section{Displacement of ATP $\gamma S^{35}$ by the nucleotides}

All the procedures involved in the binding experiment were carried out at $4^{\circ} \mathrm{C}$ (in ice) as described previously [10]. Briefly, varying concentrations $\left(10^{-8}\right.$ to $\left.10^{-3} \mathrm{M}\right)$ of ATP and UTP were added to the incubation mixture, which contained dissociated cells ( $40 \mu \mathrm{g}$ protein), ATP $\gamma \mathrm{S}^{35}$ $(3 \mu \mathrm{Ci}), \operatorname{ATP} \gamma \mathrm{S}(0.1 \mu \mathrm{M})$, and $\mathrm{Na}_{3} \mathrm{SPO}_{3}(2 \mathrm{mM})$ prior to incubation. Nonspecific binding was determined by adding ATP, to produce a final concentration of $2.5 \mathrm{mM}$, to the incubation mixture. The reaction mixtures were incubated at $4^{\circ} \mathrm{C}$ for $1 \mathrm{~h}$ whilst constantly aggitating on a shaker. No degradation of ATP $\gamma \mathrm{S}^{35}$ was detectable under those conditions based on thin layer chromatography
(TLC) assays using polyethyleneimine (PEI)-cellulose plates (data not shown). At the end of incubation, each reaction mixture was filtered on a presoaked glass fibre (GF)/C filter disc (Whatman, $24 \mathrm{~mm}$ ), and the radio-activity of the filter disc was measured using a liquid scintillation counter as described previously [10].

\section{Metabolic labelling of mucins and treatment of cultures}

Mucins were metabolically radiolabelled for $24 \mathrm{~h}$ by incubating confluent cultures (Day 5, 24 well plates, $5 \times 10^{5}$ cells $\cdot$ well $^{-1}$ ) with $02 \mathrm{~mL} \cdot$ well $^{-1}$ of a serum-free "complete" Medium 199 containing $10 \mu \mathrm{Ci} \cdot \mathrm{mL}^{-1}$ of ${ }^{3} \mathrm{H}-$ glucosamine as described previously [13]. The "complete" Medium 199 was prepared by supplementing Medium 199 with insulin $\left(5 \mu \mathrm{g} \cdot \mathrm{mL}^{-1}\right)$, transferrin $(5$ $\left.\mu \mathrm{g} \cdot \mathrm{mL}^{-1}\right)$, epidermal growth factor $\left(12.5 \mathrm{ng} \cdot \mathrm{mL}^{-1}\right), 0.2 \%$ hypothalamic extract, $0.1 \mu \mathrm{M}$ hydrocortisone, $0.1 \mu \mathrm{M}$ sodium selenite and $0.1 \mu \mathrm{M}$ retinoic acid. At the end of the $24 \mathrm{~h}$ incubation, the spent media (the pretreatment or pulsed sample) were collected, and the labelled cultures were washed twice with Dulbecco's PBS without $\mathrm{Ca}^{++}$and $\mathrm{Mg}^{++}$, before chasing for $30 \mathrm{~min}$ in serum-free "complete" Medium 199 containing varying concentrations of ATP (disodium salt, Sigma) or UTP (sodium salt) (the treatment sample). Both pretreatment and treatment samples were centrifuged to remove floating cells and stored at $-80^{\circ} \mathrm{C}$ until assayed for their ${ }^{3} \mathrm{H}$-mucin content.

\section{Quantitation of ${ }^{3} \mathrm{H}$-mucins}

High molecular weight glycoconjugates excluded from Sepharose CL-4B (Pharmacia) and resistant to hyaluronidase were defined as mucins [12], and measured as described previously [14]. Briefly, in order to compensate for variations in basal release rate among wells, "mucin release" during treatment was expressed as the ratio of the amount of ${ }^{3} \mathrm{H}$-mucin released during the treatment period to the amount of ${ }^{3} \mathrm{H}$-mucin released during the pretreatment period from each well [14].

Metabolic labelling of phosphatidylinositol (PI) phosphates and measurement of PI turnover

Metabolic labelling of PI was performed as described previously [5]. Briefly, confluent HTSE cells (Day 5) in 24 well plates were incubated for $24 \mathrm{~h}$ in the serumfree "complete" Medium $199\left(0.2 \mathrm{~mL} \cdot \mathrm{well}^{-1}\right)$ containing $5 \mu \mathrm{Ci} \cdot \mathrm{mL}^{-1}$ myo- $\left[2-{ }^{3} \mathrm{H}\right]$ inositol (Amersham; 80-120 $\left.\mathrm{Ci} \cdot \mathrm{mmol}^{-1}\right)$. At the end of the incubation, cultured wells received $\mathrm{LiCl}$ at a final concentration of $10 \mathrm{mM}$. Twenty minutes following the $\mathrm{LiCl}$ treatment, cultures were given either $4 \mu \mathrm{L}$ of plain Medium 199 or ATP or UTP, and the incubation continued for $30 \mathrm{~min}$. At the end of the $30 \mathrm{~min}$ period, the spent media were removed and then collagen gels containing epithelial cell sheets transferred into $1.5 \mathrm{~mL}$ polypropylene microfuge tubes from 
individual wells, and quickly frozen at $-80^{\circ} \mathrm{C}$ until extracted. Both extraction and measurement of inositol phosphates were carried out as described previously [5].

\section{Northern blot analysis}

Poly(A)+ribonucleic acid (RNA) was isolated from confluent cultures of hamster airway epithelial cells, using the guanidinium isothiocyanate/phenol-chloroform extraction methods [15] and poly(A) Quick messenger RNA (mRNA) purification kit (Stratagene), and electro-phoresed in 1\% agarose/formaldehyde gels [16]. The mRNA was transferred to nitrocellulose membranes, pre-hybridized for $2 \mathrm{~h}$, and then hybridized overnight at $42^{\circ} \mathrm{C}$ in a solution containing $50 \%$ formamide with $6 \times$ standard sodium citrate $(\mathrm{SSC})(1 \times \mathrm{SSC}=0.15 \mathrm{M} \mathrm{NaCl} / 15 \mathrm{mM}$ sodium citrate). The mouse $\mathrm{P}_{2 \mathrm{u}}$ receptor complementary deoxyribonucleic acid (cDNA) was a generous gift from D. Julius (Dept of Pharmacology, University of California, San Francisco, CA, USA) and was used as a probe after random prime-labelling (Boehringer Mannheim) of a 2.2 $\mathrm{kb}$ Xbal deoxyribonucleic acid (DNA) fragment, which contains the entire coding region of the $\mathrm{P}_{2 \mathrm{u}}$ receptor. The membrane was washed in $0.1 \times$ SSC containing $0.1 \%$ sodium dodecyl sulphate (SDS) at room temperature, and exposed to Kodak XAR film with two intensifying screens at $-80^{\circ} \mathrm{C}$ for 2 days.

\section{Polymerase chain reaction (PCR) and nucleotide sequenc-} ing

To obtain the hamster $\mathrm{P}_{2 \mathrm{u}}$ receptor clone, amplification was performed by using an upstream primer, 5'GGGCCAAGCGCMGTC-3', and, a downstream primer, 5'-AGCCGAATGTCCTTAG-3', which was located in the conserved sequences of the mouse and human $\mathrm{P}_{2 \mathrm{u}}$ receptor. A single-stranded cDNA was synthesized from $1 \mu \mathrm{g}$ of total RNA using the downstream primer. A quarter of the cDNA mixture was used for PCR amplification. PCR amplification was carried out as follows: $95^{\circ} \mathrm{C}$ for $5 \mathrm{~min}$ for heat treatment of samples, and 30 cycles at $94^{\circ} \mathrm{C}$ for $1 \mathrm{~min}, 42^{\circ} \mathrm{C}$ for $1 \mathrm{~min}, 72^{\circ} \mathrm{C}$ for 2 min, and a final extension at $72^{\circ} \mathrm{C}$ for $7 \mathrm{~min}$. The amplified DNA was purified and subcloned into the T-vector (Promega Corp., Madison, WI, USA) and sequenced in both directions by using a Sequenase sequencing kit (United States Biochemical Corp., Cleveland, OH, USA).

\section{Materials}

All chemicals were purchased from Sigma, unless otherwise stated.

\section{Statistics}

The difference between groups was assessed using Student's t-test for unpaired samples. A p-value equal to or less than 0.05 was considered to be significantly different.

\section{Results}

Inhibition of ATP $\gamma S^{35}$-binding by ATP and UTP

Equilibrium binding of $\mathrm{ATP} \gamma \mathrm{S}^{35}$ to freshly isolated HTSE cells was inhibited in the presence of ATP in a dose-dependent fashion with a median inhibitory concentration (IC50) of $2.9 \mu \mathrm{M}$, whereas the binding of $\mathrm{ATP} \gamma \mathrm{S}^{35}$ was inhibited by $70 \%$ in the presence of even $1 \mathrm{mM}$ UTP with $\mathrm{IC}_{50}$ of $240 \mu \mathrm{M}$ (fig. 1). One $\mathrm{mM}$ of ATP could completely inhibit the binding of ATP $\gamma \mathrm{S}^{35}$.

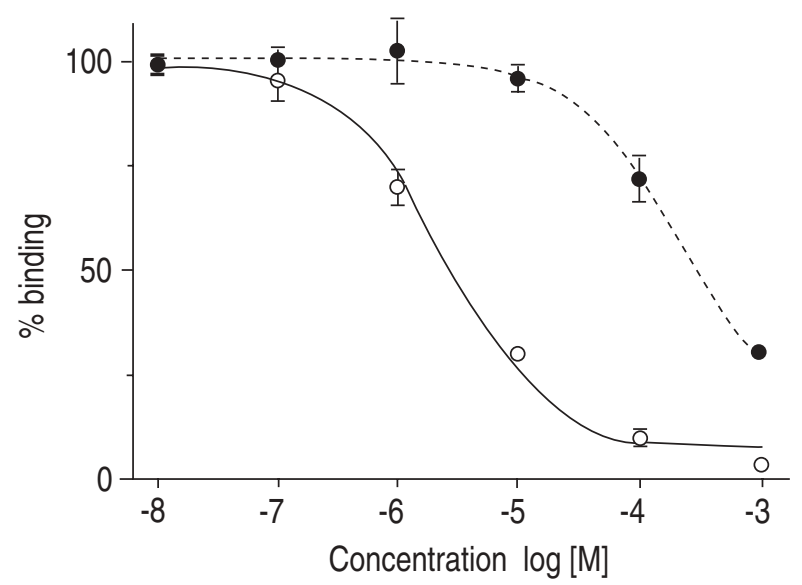

Fig. 1. - Inhibition of ATP $\gamma \mathrm{S}^{35}$-binding to primary hamster tracheal surface epithelial cells by ATP and UTP. Varying concentrations $\left(10^{-8}\right.$ to $\left.10^{-3} \mathrm{M}\right)$ of ATP ( $\left.-{ }_{-}\right)$and UTP ( $\left.\square\right)$ were added to the incubation mixture, which contained dissociated cells $(40 \mu \mathrm{g}$ protein), ATP $\gamma \mathrm{S}^{35}(3 \mu \mathrm{Ci}), \operatorname{ATP} \gamma \mathrm{S}(0.1 \mu \mathrm{mM})$, and $\mathrm{Na}_{3} \mathrm{SPO}_{3}(2 \mathrm{mM})$, and the mixture was incubated for $60 \mathrm{~min}$ at $4{ }^{\circ} \mathrm{C}$ as described in Materials and Methods. Nonspecific binding was determined by adding ATP to produce a final concentration of $2.5 \mathrm{mM}$ to the incubation mixture. Each data point represents a mean \pm SEM of triplicate samples. The overall profile was reproduced in another experiment. ATP: adenosine triphosphate; UTP: uridine triphosphate.

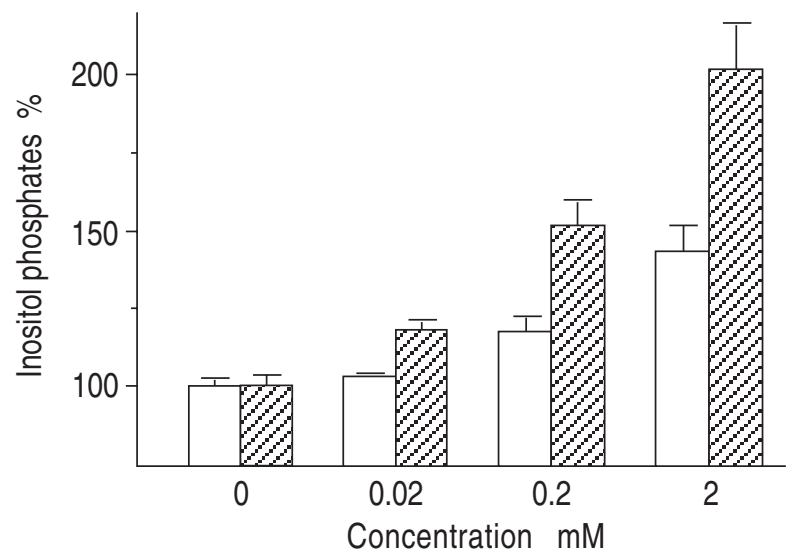

Fig. 2. - Effect of extracellular ATP and UTP on PI turnover. Confluent HTSE cells were metabolically labelled with ${ }^{3} \mathrm{H}-m y o$ inositol and treated with varying concentrations of ATP ( $\square)$ and UTP $(\square)$, and cellular contents of ${ }^{3} \mathrm{H}$-inositol phosphates were measured, as described in Materials and Methods. Each bar represents a mean \pm SEM from six cultures wells. PI: phosphatidylinositol; HTSE: hamster tracheal surface epithelial (cells). For further abbreviations see legend to figure 1 . 


\section{Effect of ATP and UTP on PI turnover}

Treatment of HTSE cells with either ATP or UTP resulted in increases in PI turnover in a dose-dependent fashion; 17 and $52 \%$ by $0.2 \mathrm{mM}$ ATP and UTP, respectively, and 43 and $101 \%$ by $2 \mathrm{mM}$ ATP and UTP, respectively (fig. 2).

\section{Effect of ATP and UTP on mucin release}

Both extracellular ATP and UTP caused increases in mucin release in a dose-dependent fashion, with almost identical potencies (fig. 3); the median effective dose (ED50) of ATP was $18.5 \mu \mathrm{M}$, whereas that of UTP was $16.8 \mu \mathrm{M}$.

Northern blot analysis and reverse transcriptase-polymerase chain reaction (RT-PCR) of HTSE mRNAs

When a total RNA preparation from HTSE cells was subjected to Northern blot analysis using the mouse $\mathrm{P}_{2 u}$ receptor cDNA as a probe, no specific band appeared (data not shown). However, Northern blot analysis with a purified mRNA preparation $(5 \mu \mathrm{g})$ revealed a single band with approximately $2.8 \mathrm{~kb}$ (fig. 4).

\section{Identification of $P_{2 u}$ receptor by using $R T-P C R$}

To identify the hamster $\mathrm{P}_{2 \mathrm{u}}$ receptor in another way, RT-PCR was performed from total RNA of the HTSE cells. As shown in figure 5, two primers were chosen from the highly conserved sequences, one in the third cytoplasmic domain (upstream) and the other in the Cterminal end (downstream). Sequence analysis of PCR product (about $0.4 \mathrm{~kb}$ ) revealed $83 \%$ homology to the human $\mathrm{P}_{2 \mathrm{u}}$ receptor and $86 \%$ homology to the mouse $\mathrm{P}_{2 \mathrm{u}}$ receptor, indicating the expression of a $\mathrm{P}_{2 \mathrm{u}}$ receptor by HTSE cells.

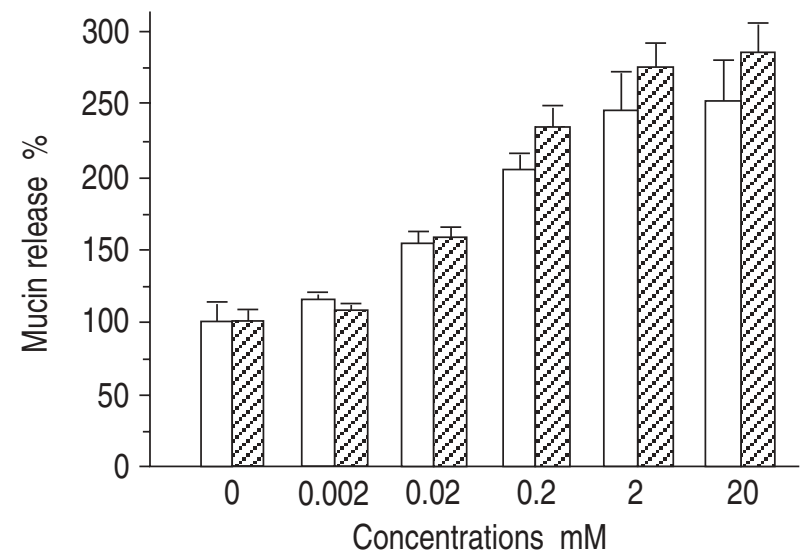

Fig. 3. - Effect of extracellular ATP and UTP on mucin release. Confluent HTSE cells were metabolically labelled with ${ }^{3} \mathrm{H}$-glucosamine and treated with varying concentrations of ATP ( $\square$ ) and UTP $(\square)$, and the amount of ${ }^{3} \mathrm{H}$-mucins in the spent media was measured, as described in Materials and Methods. Each bar represents a mean \pm SEM from four culture wells. For abbreviations see legends to figures 1 and 2 .

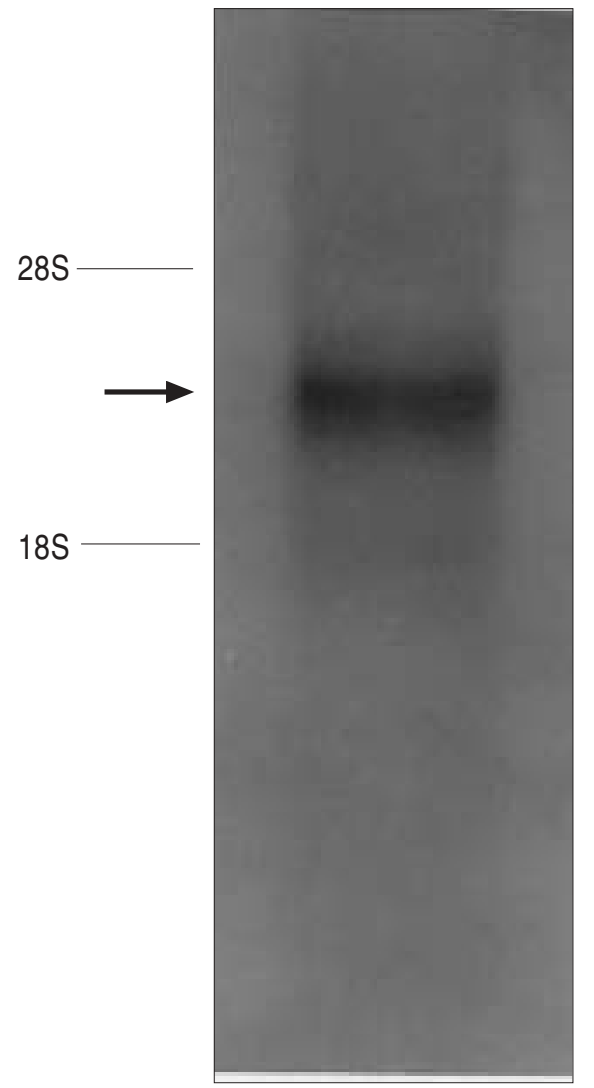

Fig. 4. - Northern blot analysis of HTSE mRNAs. Five micrograms of mRNA isolated from confluent cultures of HTSE cells was separated by $1 \%$ agarose gel electrophoresis and subjected to Northern blot analysis using a mouse $\mathrm{P}_{2 u}$ receptor cDNA as a probe, as described in Methods and Materials. A single band with $2.8 \mathrm{~kb}$ was revealed, which is similar to the size of mouse $\mathrm{P}_{2 \mathrm{u}}$ receptor mRNA $(2.4 \mathrm{~kb})$. mRNA: messenger ribonucleic acid; cDNA: complementary deoxyribonucleic acid; HTSE: hamster tracheal surface epithelial (cells).

\section{Discussion}

The present primary HTSE cell culture system has been described in detail previously [11, 12], and has been used as an in vitro model to study the biochemical mechanism of the nucleotide-induced mucin release.

In order to confirm our previous observation regarding their binding pattern [10], we first compared the ability of these nucleotides to displace ATP $\gamma \mathrm{S}^{35}$ bound to the HTSE cell surface. As can be seen in figure 1, equilibrium binding of $\mathrm{ATP} \gamma \mathrm{S}^{35}$ was inhibited in the presence of ATP in a dose-dependent fashion, with an IC50 of $2.9 \mu \mathrm{M}$, whereas the binding of ATP $\gamma \mathrm{S}^{35}$ was inhibited by only $35 \%$ in the presence of even $1 \mathrm{mM}$ UTP. This result is consistent with our previous findings [10].

The nucleotides were then compared for their ability to activate phospholipase $\mathrm{C}$. It has recently been shown that extracellular nucleotides can activate PLC in a number of cell types [6], including HTSE cells [5]. As can be seen in figure 3, both ATP and UTP increased intracellular inositol phosphate levels, although UTP seemed more potent than ATP. BROwN et al. [19] reported that UTP is more potent than ATP in its ability to accumulate inositol phosphates in a human airway epithelial cell line (CF/T43), whereas Pfeilschifter [20] showed that they are equipotent in rat renal mesangial cells. 
Human $\mathrm{P}_{2 \mathrm{u}}$

Mouse $\mathrm{P}_{2 \mathrm{u}}$

Hamster

GGGCCAAGCGCAAGTCCGTGCGCACCATCGCCGTGGTGCTGGCTGTCTTCGCCCT 1009 |||||||||||||||||||||||||||||||||||||||||||||| $\mid$ GGGCCAAGCGCAAGTCTGTGCGCACCATTGCCTTGGTACTGGCCGTCTTCGCCCT 1036 Upstream primer

||| || ||||| ||| |||| |||||||||| |||| TGTACGAACCATCGCCCTGGTGCTGGCCGTCTTTACCCT

CTGCTTCCTGCCATTCCACGTCACCCGCACCCTCTACTACTCCTTCCGCTCGCTG 1064 \|\|\|\|\|\|$\|\mid\|\|\|\|\|\|\|\|\|\|\|\|\|\|\|\|\|\|\|\|\|\|\|\|\|$ CTGCTTTCTGCCTTTCCACGTCACGCGCACCCTCTACTACTCCTTCCGATCACTT 1091

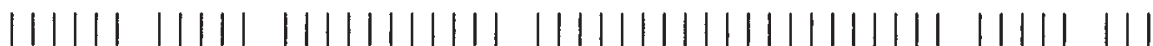
CTGCTTCCTGCCCTTCCACGTCACCCGCACCCTCTACTACTCCTTTCGATCTCTT

GACCTCAGCTGCCACACCCTCAACGCCATCAACATGGCCTACAAGGTTACCCG. . 1117 $|\|\|\|\|\|\|\|\|\|\|\|\|\|\|\|\|\|\|\|\|\|\|\|\| \||||||||||$ GACCTCAGCTGCCACACCCTCAACGCCATCAACATGGCATATAAGATCACCCGGC 1146

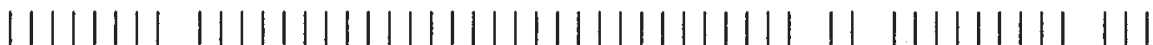
GACCTCAGTTGCCACACCCTCAACGCCATCAACATGGCGTACAAGATCACCAGGC . GCTGGCCAGTGCTAACAGTTGCCTTGACCCCGTGCTCTACTTCCTGGCTGGGCA 1171

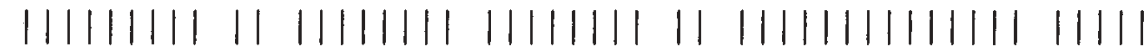
CGCTGGCCAGCGCCAACAGTTGTCTTGACCCGGTACTCTACTTCCTGGCAGGGCA 1201 |||||||||||||||||||||||||||||||||||||||||||||||||| CACTGGCCAGCGCCAACAGTTGTCTTGATCCTGTGCTCTACTTCCTGGCAGGGCA GAGGCTCGTACGCTTTGCCCGAGATGCCAAGCCACCCACTGGCCCCAGCCCTGCC 1226 ||| || || ||||||||||||||||||||||||||||| || | ||| | GAGACTTGTCCGCTTTGCCCGAGATGCCAAGCCACCCACGGAGCCTACCCCCAGC 1256 |||||||||||||||||||||||||||||||||||||||||||||||||| GAGACTCGTCCGGTTTGCCCGAGACGCCAAGCCACCCACAGAGCCCAGCCCCAGG ACCCCGGCTCGCCGCACGCTGGGCCTGCGCAGATCCGACAGAACTGACATGCAGA 1281 | | |||||| |||||||||||||||||| | ||||||||| | | | CCACAGGCTCGTCGCAAGCTGGGCCTGCACAGGCCTAACAGAACTGTGAGGAA. . 1309 || ||||||||||||||||||||||||||||||||| |||| | CCCCAGGCTCATCGCAGGCTGGGCCTGCACAGGTCTCACAGGACTGACACTGTGA GGATAGGAGATGTGTTGGGCAGCAGTGAGGACTCTAGGCGGACAGAGTCCACGCC 1336

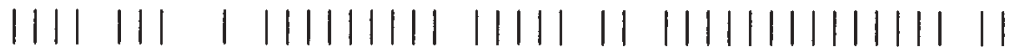
....... AGATTTGTCAGTCAGCAGTGACGACTCAAGACGGACAGAGTCCACACC 1357

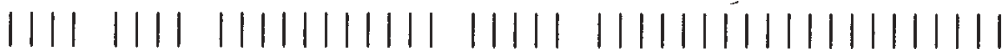
GGA. . AAGATGTGTCGGTCAGCAGTGATGACTCCAGACGGACAGAGTCCACACC GGCTGGTAGCGAGAACACTAAGGACATTCGGCTGTAGGAGCAGAACAC

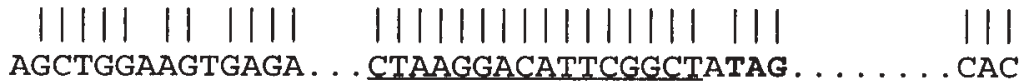
\|\|$\||||| \mid$ Downstream primer AGCTGGGAACGACA. . .

Fig. 5. - Partial nucleotide sequence of hamster MUC1 mucin gene and the comparison of the sequence with those of human and mouse MUC1 mucin genes. Total RNAs from confluent HTSE cells were subjected to RT-PCR using two primers (underlined) which contain exactly homologous sequences between the human [17] and mouse [18] MUC1 cDNAs. A resulting PCR product $(0.4 \mathrm{~kb})$ was then subjected to nucleotide sequencing as described in Methods. Note that there is a great sequence homology among the three species. RT-PCR: reverse transcriptase-polymerase chain reaction; RNA: ribonucleic acid. For further abbreviations see legend to figure 4.

Lastly, the ability of the nucleotides to stimulate mucin release was compared. Figure 3 shows that extracellular UTP stimulated mucin release in a dose-dependent fashion, and its dose-effect relationship was almost identical with that of ATP. The lack of an exact correlation between the degree of mucin release and that of PI turnover by the nucleotides may suggest that activation of PLC may not be the sole signal transduction mechanism responsible for mucin release by these nucleotides. Alternatively, it might also be possible that these nucleotides 
activate different receptors leading to either different signal transduction pathways or different degrees of PLC activation. Mотте et al. [21] have demonstrated the coexistence of the $\mathrm{P}_{2 \mathrm{y}}$ and $\mathrm{P}_{2 \mathrm{u}}$ receptors on aortic endothelial cells, which are coupled to PLC in different magnitudes. Thus, although the agonist potency order seems to strongly suggest that mucin release by HTSE cells involves the $\mathrm{P}_{2 \mathrm{u}}$ receptor type on the secretory cells, it is possible that some nonsecretory cells contaminating the present cultured HTSE cells may contain other cell-surface nucleotide receptors, such as $\mathrm{P}_{2 \mathrm{y}}$, which are differentially coupled to PLC. Such a situation would obscure the direct correlation between increases in PI turnover by HTSE cells and increases in mucin release by secretory cells alone in the HTSE cells. One way to resolve this problem would be to use selective antagonists of both $\mathrm{P}_{2 \mathrm{y}}$ and $\mathrm{P}_{2 \mathrm{u}}$ receptors; however, they are not available at the present time.

Combined with the previous data [2], a new potency order of nucleotides in stimulating mucin release from HTSE cells becomes: UTP $=\mathrm{ATP}=\mathrm{ATP} \gamma \mathrm{S}>$ adenosine diphosphate $(\mathrm{ADP})>2$-methylthio ATP $>\alpha, \beta$-methylene ATP $>\beta, \gamma$-methylene ATP. This is in agreement with the recent data of LETHEM et al. [4], which showed that both ATP and UTP induced similar secretory responses but that 2-methylthio ATP was not effective in human airway epithelial explants. Based on this potency order, it is likely that mucin release by nucleotides involves "pyriminoceptors" [7] or "nucleotide/ $\mathrm{P}_{2 \mathrm{u}}$ " purinoreceptors [6].

Most interesting and intriguing is, however, the discrepancy between the mucin release and the binding potencies between these two nucleotides. Since the binding experiment was performed at $4^{\circ} \mathrm{C}$, significant changes in actual concentrations of these nucleotides, due to their differential degradation by 5 '-nucleotidase, is rather unlikely. Therefore, given that ATP, ATP $\gamma \mathrm{S}$ and UTP are almost equipotent in mucin release ([2] and fig. 3), one would expect both ATP and UTP to be almost equipotent in displacing ATP $\gamma \mathrm{S}^{35}$. Therefore, a marked difference in their binding pattern (fig. 1) seems to suggest that cell surface binding sites for ATP and UTP are quite different, and that a population of receptors with common binding sites for these nucleotides probably includes the $\mathrm{P}_{2 \mathrm{u}}$ receptor responsible for mucin release. On the other hand, the difference could be due to the presence of the two different binding domains within the $\mathrm{P}_{2 \mathrm{u}}$ receptor, one for ATP and the other for UTP, as recently suggested by ERB et al. [22].

Finally, since the present cultured HTSE cells are highly enriched with secretory cells, we intended to determine whether HTSE cells express the $\mathrm{P}_{2 \mathrm{u}}$ receptor gene, which was recently cloned from mouse neuroblastoma cells [18]. This mouse $\mathrm{P}_{2 \mathrm{u}}$ receptor gene was transfected and stably expressed in a human leukaemia cell line, and its gene product (53 $\mathrm{kDa}$ protein) has recently been identified as the $\mathrm{P}_{2 \mathrm{u}}$ receptor [22]. Northern blot analysis of total RNAs did not show any signal, whereas that of purified mRNAs revealed a single band with approximately $2.8 \mathrm{~kb}$ (fig. 4). We believe that this $2.8 \mathrm{~kb}$ mRNA is indeed the hamster $\mathrm{P}_{2 u}$ receptor, since: 1) its size is similar to the size from other species, i.e. $2.4 \mathrm{~kb}$ for the mouse [18], and $2.1 \mathrm{~kb}$ for humans [17]; 2) a RT-PCR product $(0.4 \mathrm{~kb})$ obtained from HTSE total RNAs was highly homologous in its nucleotide sequence to that of either the human $(83 \%)$ or mouse $(86 \%) \mathrm{P}_{2 \mathrm{u}}$ receptor (fig. 5); and 3) Northern blot analysis of HTSE mRNAs using this RT-PCR product as a probe revealed an identical band of $2.8 \mathrm{~kb}$ (data not shown). Nucleotide sequencing of the full-length hamster $\mathrm{P}_{2 \mathrm{u}}$ receptor is currently under way.

In summary, HTSE cells express the $\mathrm{P}_{2 \mathrm{u}}$ receptor gene, the translation product of which appears to bind both to UTP and ATP and also to be responsible for extracellular mucin release by these nucleotides, most likely through PLC activation. This primary HTSE cell culture system may serve as a useful model for further study of the molecular basis of the nucleotide-induced mucin release.

\footnotetext{
Acknowledgements: The authors thank D. Julius (University of California, San Francisco, CA, USA) for his generous gift of the mouse $\mathrm{P}_{2 \mathrm{u}}$ receptor cDNA, and E. Moreton for his critical review of this manuscript.
}

\section{References}

1. Kim KC. Cellular and biochemical mechanisms of airway epithelial mucin release. In: Brody J, Tkachuk V, Center D, eds. Signal Transduction in Lung Cells: Lung Biology in Health and Disease. Vol. 65. New York, Marcel Dekker, 1993; pp. 309-321.

2. Kim KC, Lee BC. $\mathrm{P}_{2}$ purinoceptor regulation of mucin release by airway goblet cells in primary culture. $\mathrm{Br} \mathrm{J}$ Pharmacol 1991; 103: 1053-1056.

3. Kim KC, Wilson AK, Lee BC. Nucleotides and mucin release from cultured airway epithelial cells. Chest 1992; 101: 68S-69S.

4. Lethem MI, Dowell ML, Van Scott M, et al. Nucleotide regulation of goblet cells in human airway epithelial explants: normal exocytosis in cystic fibrosis. $A m J$ Respir Cell Mol Biol 1993; 9: 315-322.

5. Kim KC, Zheng QX, Van Seuningen I. Involvement of a signal transduction mechanism in ATP-induced mucin release from cultured airway goblet cells. Am J Respir Cell Mol Biol 1993; 8: 121-125.

6. O'Connor SE. Recent developments in the classification and functional significance of receptors for ATP and UTP, evidence for nucleotide receptors. Life Sci 1992; 50: $1657-1664$.

7. Seifert R, Schulz G. Involvement of pyrimidinoceptors in the regulation of cell functions by uridine and by uracil nucleotides. Trends Pharmacol Sci 1989; 10: 365-369.

8. Benali R, Pierrot D, Zahm JM, de Bentzmann S, Puchelle E. Effect of extracellular ATP and UTP on fluid transport by human nasal epithelial cells in culture. Am J Respir Cell Mol Biol 1994; 10: 363-368.

9. Mason SJ, Paradiso AM, Boucher RC. Regulation of transepithelial ion transport and intracellular calcium by extracellular ATP in human normal and cystic fibrosis airway epithelium. Br J Pharmacol 1991; 103: 16491656.

10. Kim KC, Zheng QX, Wilson AK, Lee BC, Berman JS. Binding kinetics of $\mathrm{ATP} \gamma \mathrm{S}^{35}$ on cultured primary tracheal surface epithelial cell. Am J Respir Cell Mol Biol 1994; 10: 154-159. 
11. Wasano K, Kim KC, Niles RM, Brody JS. Membrane differentiation markers of airway epithelial secretory cells. J Histochem Cytochem 1988; 36: 167-178.

12. Kim KC, Rearick JI, Nettesheim P, Jetten AM. Biochemical characterization of mucous glycoproteins synthesized and secreted by hamster tracheal epithelial cells in primary culture. J Biol Chem 1985; 260: 4021-4027.

13. Kim KC, Opaskar-Hincman H, Bhaskar KR. Secretions from primary hamster tracheal surface epithelial cells in culture: mucin-like glycoproteins proteoglycans and lipids. Exp Lung Res 1989; 15: 299-314.

14. Kim KC, Wasano K, Niles RM, Schuster JE, Stone PJ, Brody JS. Human neutrophil elastase releases cell surface mucins from primary cultures of hamster tracheal epithelial cells. Proc Natl Acad Sci USA 1987; 84: 9304-9308.

15. Chomcznski P, Sacchi N. Single-step method of RNA isolation by acid guanidinium thiocyanate-phenolchloroform extraction. Anal Biochem 1987; 162: 156159.

16. Sambrook J, Fritsch EF, Maniatis T. In: Molecular cloning: a laboratory manual. 2nd edn. Plainview, New York, Cold Spring Harbor Lab., 1989.
17. Parr CW, Sullivan DM, Paradiso AM, et al. Cloning and expression of a human $\mathrm{P}_{2 u}$ nucleotide receptor, a target for cystic fibrosis pharmacotherapy. Proc Natl Acad Sci USA 1994; 91: 3275-3279.

18. Lustig KD, Shiau AK, Brake AJ, Julius D. Expression cloning of an ATP receptor from mouse neuroblastoma cells. Proc Natl Acad Sci USA 1993; 90: 5113-5117.

19. Brown HA, Lazarowski ER, Coucher RC, Harden TK. Evidence that UTP and ATP regulate phospholipase C through a common extracellular 5'-nucleotide receptor in human airway epithelial cells. Mol Pharmacol 1991; 40: 648-655.

20. Pfeilschifter J. Comparison of extracellular ATP and UTP signaling in rat renal mesangial cells. Biochem $J$ 1990; 272: 469-472.

21. Motte S, Pirotton S, Boeynaems JM. Heterogeneity of ATP receptors in aortic endothelial cells: involvement of $\mathrm{P}_{2 \mathrm{y}}$ and $\mathrm{P}_{2 \mathrm{u}}$ receptors in the inositol phosphate response. Circ Res 1993; 72: 504-510.

22. Erb L, Lustig KD, Sullivan DM, Turner JT, Weisman GA. Functional expression and photoaffinity labeling of a cloned $\mathrm{P}_{2 \mathrm{u}}$ purinergic receptor. Proc Natl Acad Sci USA 1994; 90: 10449-10453. 